\title{
Novel cancer therapies: treatments driven by tumour biology
}

\author{
Ramya Ramaswami, Victoria Harding, Thomas Newsom-Davis
}

Department of Oncology, Chelsea \& Westminster Hospital NHS Foundation Trust, London, UK

\section{Correspondence to Dr Thomas Newsom-Davis, Department of Oncology, Chelsea \& Westminster Hospital NHS Trust, 369 Fulham Road, London SW10 9NH, UK; tom.newsom-davis@chelwest. nhs.uk}

Received 26 November 2012 Revised 9 July 2013

Accepted 19 September 2013

\section{ABSTRACT}

The traditional view is that treatments within oncology largely consist of chemotherapy, which aims to maximise damage to the rapidly dividing cancer cells but often at the expense of normal cells and overall quality of life for the patient. The development of anticancer drugs has changed from the serendipitous discoveries of the past, to today's purposeful targeting of cancer cells which takes advantage of novel technological developments and a greater understanding of tumour biology. The aim of these new treatments is to affect the essential function of the cancer cell while sparing normal cells, and limiting side effects. The phenotypic characteristics of tumours, such as unregulated growth signalling, development of new vascular systems and the evasion of immune destruction are used to identify potential drug targets. Here we review the clinical evidence and molecular mechanisms for novel therapies that are currently in use and those that are in development.

\section{INTRODUCTION}

Historically, it was thought that cancer cells were insular entities, self-proliferating independently of their environment. Subsequently however, it has been demonstrated that changes in the cancer cells and the local tumour microenvironment cause tumourigenic traits. Cancer is a heterogenous condition and so deciphering its biology is difficult. One view sees cancer as consisting of genetically erroneous and unstable cells that have a perpetual drive to proliferate and do not adhere to the usual regulatory mechanisms that would otherwise lead to normal cell death. Hanahan and Weinberg ${ }^{1}$ amalgamated the features of tumour biology and defined the 'Hallmarks of cancer', which highlight the phenotypic characteristics of cancer cells in their capacity to grow, resist the usual mechanisms of cell death and invade (figure 1). Four of these hallmarks have been the main focus of drug development to date and will be explored here: inhibition of proliferative signals; targeting the vascular supply of the tumour (angiogenesis); exploiting the genomic instability of tumours; tackling immune evasion by the cancer cells and the ability of cancer cells to evade immune detection.

\section{INHIBITION OF PROLIFERATIVE SIGNALLING}

Normal cellular homeostasis is achieved by a complex network of cellular signals (figure 2). External growth signals instruct cells via their surface receptors, to grow, repair and divide. Intracellular pathways pass from the cell surface to the nucleus, and if there is no such signal received at the nucleus, cell growth and division cease. By contrast, cancer cells can stimulate their own growth without these external signals. This occurs through three mechanisms: constitutive activation of cell surface receptors, overexpression of cell surface receptors and cancer cell release of its own growth signal.

The epidermal growth factor receptor (EGFR) family consists of a number of extracellular protein receptors which, upon activation by their ligand, can propagate downstream signalling and constitutive pathway activation (table 1). These signalling cascades are implicated in gene transcription for cell proliferation, angiogenesis and invasion. Inhibitors of EGFR pathways are a group of targeted therapies that interrupt these processes and have been shown to be important treatments in lung, breast and colorectal cancers.

\section{Targeting EGFR}

EGFR (ErbB-1) is an attractive signalling pathway target as it regulates many functions including cell proliferation, migration and angiogenesis. In colorectal cancer, the gene for EGFR is overexpressed in $60-80 \%$ of cases. In the CRYSTAL (Cetuximab Combined with Irinotecan in First-Line Therapy for Metastatic Colorectal Cancer) trial, cetuximab in combination with chemotherapy improved response rates compared with chemotherapy alone, with a HR of $1.40 \quad(95 \%$ CI 1.12 to 1.77 ; $\mathrm{p}=0.004)$. This equated to a modest improvement in median overall survival (OS, 19.9 vs 18.6 months). ${ }^{2}{ }^{3}$ Cetuximab is also recommended for use in conjunction with radiotherapy for patients with locally advanced squamous cell cancer of the head and neck (table 2). Combination treatment significantly prolongs progression-free survival, as well as increasing OS (49.0 vs 29.3 months, HR $0.74 ; \mathrm{p}=0.03){ }^{4}$

The use of cetuximab has also led to greater knowledge regarding the link between Kirsten rat sarcoma (KRAS), a member of the RAS gene family, which is linked closely to the activity of EGFR. In the proportion of colorectal cancers in which there are KRAS mutations, there is a very poor response to anti-EGFR monoclonal antibodies as a result of activation of alternative signalling pathways. Consequently, the presence of a KRAS mutation is a predictive biomarker which is commonly tested in colorectal cancer patients to guide the possible use of EGFR targeted monoclonal antibodies. ${ }^{5}$

The identification of such biomarkers has revolutionised treatment in oncology. Nowhere is this better seen than in non-small cell lung cancer (NSCLC) where mutations in the kinase domain of EGFR have been found to correlate with impressive responses to EGFR tyrosine kinase inhibitors (TKI) such as gefitinib and erlotinib, and to be associated 


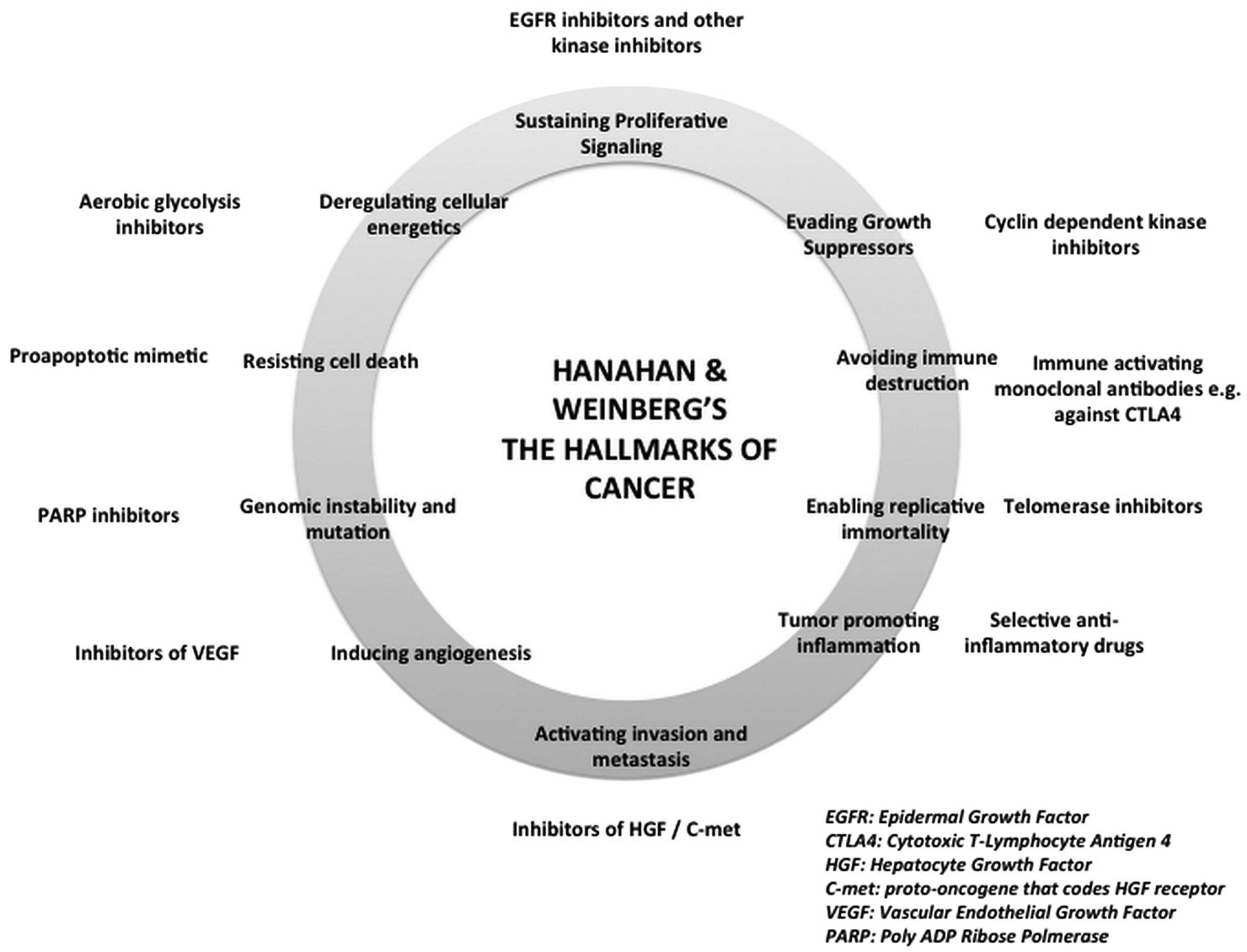

Figure 1 Hallmarks of cancer-adapted from Hanahan and Weinberg illustrating the phenotypic characteristics of cancer.

with a better overall prognosis. EGFR mutations occur in approximately $10-15 \%$ of all lung cancer patients, are most commonly found in those with adenocarcinoma histology and who do not smoke, and are now routinely tested for at diagnosis. ${ }^{6-8}$ Advanced stage lung cancer patients with an EGFR mutation who receive erlotinib instead of platinum-based chemotherapy, have an improved progression-free survival (PFS, 9.7 vs 5.2 months (HR $0.37,95 \%$ CI 0.25 to $0.54 ; \mathrm{p}<0.0001$ ),

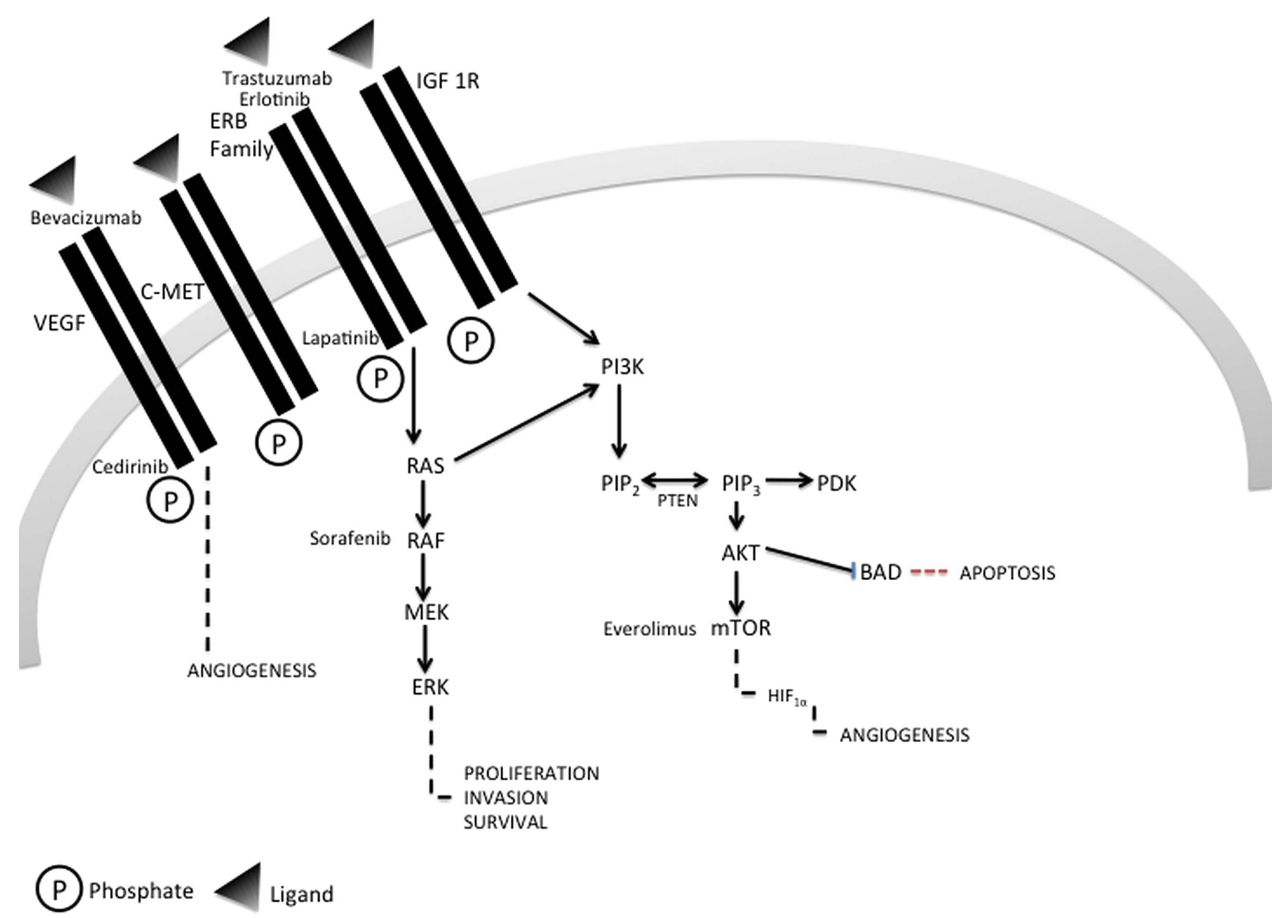

Figure 2 Cancer drug targets in cellular pathways. 
Table 1 The epidermal growth factor receptor family

\begin{tabular}{llll}
\hline Receptor & $\begin{array}{l}\text { Alternative } \\
\text { name }\end{array}$ & Ligands & Licensed drugs \\
\hline ErbB-1 & EGFR & $\begin{array}{l}\text { EGF, TGF- } \alpha \text {, HB-EGF, } \\
\text { amphiregulin, betacellulin, } \\
\text { epigen, epiregulin } \\
\text { Homodimer (no ligand) }\end{array}$ & $\begin{array}{l}\text { Gefitinib, erlotinib, } \\
\text { afatinib }\end{array}$ \\
ErbB-2 & Her2/c-neu & $\begin{array}{l}\text { Trastuzumab, } \\
\text { lapatinib, sunitinib, } \\
\text { sorafenib }\end{array}$ \\
ErbB-3 & Her 3 & $\begin{array}{l}\text { Neuregulin 1, 2 } \\
\text { HB-EGF, betacellulin, } \\
\text { epiregulin, neuregulin } \\
1,2,3,4\end{array}$ & \\
\hline
\end{tabular}

EGFR, epidermal growth factor receptor; HB-EGF, heparin-binding EGF-like growth factor; TGF- $\alpha$, transforming growth factor- $\alpha$.

a significantly reduced risk of progression or death, and experience a favourable side effect profile. ${ }^{9}$ Similar benefits have been observed with gefitinib. Although no OS benefit has been demonstrated for these agents, this most likely reflects the crossover design of the trials in which all patients receive an EGFR TKI at some stage in their treatment.

\section{Targeting HER2}

Amplification of the human epidermal growth factor receptor 2 (HER2) gene and subsequent overexpression of the HER2 receptor is noted in approximately $20 \%$ of breast cancers. ${ }^{10}$ In this population which is known to have a poorer outcome and worse response to conventional chemotherapy, the addition of trastuzumab, a humanised monoclonal antibody targeting HER2, to conventional treatment reduces the risk of disease recurrence by up to $46 \%$ and increases OS (HR 0.66, $\mathrm{p}=0.0115) .{ }^{11}$ In advanced stage disease, the addition of trastuzumab to paclitaxel results in longer median times to disease progression compared with paclitaxel alone $(11.8$ vs 5.9 months; HR $0.60 ; \mathrm{p}<0.001)$, however, median OS is similar in both groups $(\mathrm{OS}=26.7$ vs 25.2 months; HR 0.88 ; $\mathrm{p}=0.16){ }^{12}$

Trastuzumab is also licensed as first-line treatment in combination with chemotherapy in HER2-positive gastric cancer, which is an aggressive tumour with poorer outcomes (table 2).

Table 2 Summary of targeted agents and licensed uses

\begin{tabular}{|c|c|c|c|c|c|}
\hline Agent & $\begin{array}{l}\text { Cancer } \\
\text { Hallmark }\end{array}$ & Mode of Action & Site/Context & Common side effects & NICE Guidance \\
\hline Panitumumab & $\begin{array}{l}\text { Growth } \\
\text { signalling }\end{array}$ & $\begin{array}{l}\text { Monoclonal Abs } \\
\text { EGFR }\end{array}$ & Colorectal—metastatic & $\begin{array}{l}\text { Dermatological reactions, } \\
\text { pulmonary complications, } \\
\text { electrolyte disturbances }\end{array}$ & Not recommended as monotherapy \\
\hline Trastuzumab & $\begin{array}{l}\text { Growth } \\
\text { signalling }\end{array}$ & $\begin{array}{l}\text { Monoclonal Abs } \\
\text { HER2 }\end{array}$ & $\begin{array}{l}\text { Breast-in early breast } \\
\text { cancer or metastatic } \\
\text { HER2 +++ }\end{array}$ & $\begin{array}{l}\text { Cardiotoxicity, allergic reaction, } \\
\text { hypertension, neutropenia, } \\
\text { diarrhoea, nausea and vomiting }\end{array}$ & $\begin{array}{l}\text { Given at 3-week intervals for } 1 \text { year or until disease } \\
\text { recurrence treatment option for women with } \\
\text { early-stage HER2-positive breast cancer neoadjuvant } \\
\text { or adjuvant }\end{array}$ \\
\hline Trastuzumab & $\begin{array}{l}\text { Growth } \\
\text { signalling }\end{array}$ & $\begin{array}{l}\text { Monoclonal Abs } \\
\text { HER2 }\end{array}$ & $\begin{array}{l}\text { Gastric_in metastatic } \\
\text { pts HER2 +++ }\end{array}$ & $\begin{array}{l}\text { Cardiotoxicity, allergic reaction, } \\
\text { hypertension, neutropenia, } \\
\text { diarrhoea, nausea and vomiting }\end{array}$ & Not recommended \\
\hline Lapatinib & $\begin{array}{l}\text { Growth } \\
\text { signalling }\end{array}$ & TKI & $\begin{array}{l}\text { Breast-in metastatic } \\
\text { setting }\end{array}$ & $\begin{array}{l}\text { Anorexia, headache, } \\
\text { cardiotoxicity, diarrhoea }\end{array}$ & Not recommended \\
\hline Cetuximab & $\begin{array}{l}\text { Growth } \\
\text { signalling }\end{array}$ & $\begin{array}{l}\text { Monoclonal Abs } \\
\text { EGFR }\end{array}$ & $\begin{array}{l}\text { Colorectal+head/neck- } \\
\text { both in first-line } \\
\text { +metastatic }\end{array}$ & $\begin{array}{l}\text { Dermatological reactions, } \\
\text { electrolyte disturbance, } \\
\text { anaphylaxis }\end{array}$ & $\begin{array}{l}\text { In combination first line (with 5FU/folinic acid and } \\
\text { oxaliplatin) when surgery carried out, mets only in } \\
\text { liver, neoadjuvantly to shrink. In metastatic setting } \\
\text { with irinotecan }\end{array}$ \\
\hline $\begin{array}{l}\text { Erlotinib/ } \\
\text { Gefitinib }\end{array}$ & $\begin{array}{l}\text { Growth } \\
\text { signalling }\end{array}$ & TKI & $\begin{array}{l}\text { Lung-first-line in EGFR } \\
+ \text { pts and in second-line } \\
\text { NSCLC }\end{array}$ & $\begin{array}{l}\text { Dermatological reaction, } \\
\text { diarrhoea, nausea }\end{array}$ & $\begin{array}{l}\text { Use in first line in presence of EGFR mutation, and } \\
\text { in the context of progression }\end{array}$ \\
\hline Everolimus & $\begin{array}{l}\text { Growth } \\
\text { signalling }\end{array}$ & mTOR inhibitor & $\begin{array}{l}\text { RCC-second-line } \\
\text { treatment }\end{array}$ & $\begin{array}{l}\text { Dermatological reaction, } \\
\text { diarrhoea, nausea, loss of } \\
\text { appetite }\end{array}$ & Use in metastatic/second line setting in RCC \\
\hline Temsirolimus & $\begin{array}{l}\text { Growth } \\
\text { signalling }\end{array}$ & mTOR inhibitor & $\begin{array}{l}\text { RCC-second-line } \\
\text { treatment }\end{array}$ & $\begin{array}{l}\text { Dermatological reaction, } \\
\text { diarrhoea, nausea, loss of } \\
\text { appetite }\end{array}$ & Use in metastatic/second line setting in RCC \\
\hline Bevacizumab & Angiogenesis & $\begin{array}{l}\text { Monoclonal Abs } \\
\text { VEGF }\end{array}$ & $\begin{array}{l}\text { Breast, colorectal, RCC, } \\
\text { lung, ovarian, Brain-in } \\
\text { metastatic setting }\end{array}$ & $\begin{array}{l}\text { Hypersensitivity reaction, nausea, } \\
\text { vomiting, high blood pressure, } \\
\text { VTE, bleeding }\end{array}$ & $\begin{array}{l}\text { Available for breast, brain and ovarian cancer on } \\
\text { cancer drugs fund. } \\
\text { Licensed for second-line use in metastatic colorectal } \\
\text { cancer }\end{array}$ \\
\hline Sunitinib & Angiogenesis & TKI & $\begin{array}{l}\text { RCC-In first-line } \\
\text { metastatic setting }\end{array}$ & $\begin{array}{l}\text { Thyroid dysfunction, hypertension, } \\
\text { diarrhoea, dermatological reaction }\end{array}$ & In first line metastatic setting \\
\hline Sorafenib & Angiogenesis & TKI & $\begin{array}{l}\mathrm{HCC}-\text { In first-line } \\
\text { metastatic setting }\end{array}$ & $\begin{array}{l}\text { Diarrhoea, hypertension, sore } \\
\text { mouth, dermatological reaction }\end{array}$ & Use in HCC in first line setting \\
\hline Imatinib & $\begin{array}{l}\text { Cell } \\
\text { Proliferation }\end{array}$ & TKI & CML-First-line & $\begin{array}{l}\text { Nausea, diarrhoea, fluid retention, } \\
\text { neutropenia, rash, bleeding }\end{array}$ & Use in first line in CML \\
\hline Vemurafenib & $\begin{array}{l}\text { Cell } \\
\text { Proliferation }\end{array}$ & TKI & $\begin{array}{l}\text { Melanoma-metastatic } \\
\text { setting }\end{array}$ & $\begin{array}{l}\text { Arthralgia, skin rash, } \\
\text { photosensitivity }\end{array}$ & $\begin{array}{l}\text { In metastatic setting - those who express BRAF } \\
\text { V600E mutation }\end{array}$ \\
\hline Abiraterone & $\begin{array}{l}\text { Cell } \\
\text { Proliferation }\end{array}$ & $\begin{array}{l}\text { Hormonal agent } \\
\text { against CYP17 }\end{array}$ & $\begin{array}{l}\text { Prostate-metastatic } \\
\text { setting }\end{array}$ & $\begin{array}{l}\text { Hypokalaemia, hypertension, fluid } \\
\text { retention }\end{array}$ & Recommended in refractory prostate cancer \\
\hline
\end{tabular}

CML, chronic myeloid leukaemia; EGFR, epidermal growth factor receptor; mTOR, mammalian target of rapamycin; NSCLC, non-small cell lung cancer; TKI, tyrosine kinase inhibitor;

VEGF, vascular endothelial growth factor; RCC, renal cell carcinoma; HCC, hepatocellular carcinoma; NICE, National Institute of Health and Clinical Excellence. 
The addition of trastuzumab improves OS by 2 months compared with standard therapy. ${ }^{13}$ Though this may seem like a small benefit, the identification of HER2 in gastric cancer is an important step forward in understanding the tumour biology of this difficult-to-manage disease.

Lapatinib, a HER2-specific TKI, inhibits signalling through the HER2 receptor through ligand-induced signalling blockade. Lapatinib appears to have a synergistic effect by causing accumulation of HER2 at the cell surface, thereby enhancing the effects of trastuzumab. Correspondingly, in HER2-positive metastatic breast cancer, the combination of lapatinib and trastuzumab is more effective than lapatinib alone in terms of PFS and response rate. ${ }^{14}$

\section{Downstream signalling: mammalian target of rapamycin}

Whereas the EGFR family provides anticancer drug targets at the cell receptor level, knowledge of cellular control downstream of this is equally important so that all key regulators of cell growth are explored. The mammalian target of rapamycin (mTOR) is a downstream molecule within the intracellular signalling pathway which regulates a variety of functions, including cellular growth, metabolism, proliferation and angiogenesis. Everolimus and temsirolimus are inhibitors of mTOR and are licensed in the treatment of metastatic renal cell cancer. Therapy in renal cell cancer was previously limited to toxic cytokine therapies, such as interferon- $\alpha$ and interleukin 2, however, when used in the context of relapsed disease, everolimus increases median PFS from 1.87 to 4.90 months compared with placebo. ${ }^{15} 16$ Everolimus is also being trialled in the context of metastatic breast cancer as it appears that targeting mTOR may be applicable to a range of tumour types.

\section{TARGETING ANGIOGENESIS}

Cancer cells are able to recruit new blood vessels to supply the necessary nutrients for tumour growth, a process termed neoangiogenesis, via the secretion of pro-angiogenic factors. All cells lacking in oxygen will produce a transcription factor (hypoxia-inducible factor, HIF), which stimulates the release of vascular endothelial growth factor (VEGF) that binds to the cell surface receptors (VEGF-receptor, VEGF-R) of nearby endothelial cells. This process results in formation of new blood vessels in the vicinity of the cell. Expression of VEGF is increased in a number of tumours including breast, lung and ovarian cancers, and often confers a poor prognosis. Over the past decade, exploring the angiogenesis hallmark and targeting the overexpression of VEGF by cancer cells has been an important development in novel anticancer therapy. ${ }^{17}$

\section{VEGF inhibitors}

Bevacizumab is a monoclonal antibody that inhibits all active isoforms of VEGF and which neutralises the ability of VEGF to bind to its receptor on endothelial cells. This results in the prevention of neovascular formation by pruning abnormal vessels and promoting tumour endothelial cells apoptosis, leading to decreased interstitial fluid pressures within the tumour and enabling enhanced delivery of oxygen and chemotherapeutic drugs. Bevaciuzumab is an attractive adjunct to standard chemotherapeutics in colorectal, breast and ovarian cancers. For example, in advanced colorectal cancer, bevacizumab can be used as a first-line option, and has been shown to improve PFS when added to chemotherapy in the first-line setting (10.4 vs 7.1 months, HR 0.62; $p=0.001) .{ }^{18-20}$

It has been suggested there is a particular role for bevacizumab in vascular tumours. In one such example, the primary brain tumour glioblastoma multiforme (GBM) where the median survival from diagnosis is just 3-6 months, patients with recurrent disease were treated with bevacizumab and the chemotherapeutic agent irinotecan. In 20 of the 35 patients, there was a $30 \%$ decrease in size of the tumour, whilst 6 month OS was $77 \%(95 \%$ CI $64 \%$ to $92 \%) .^{21}$

The effects of bevacizumab in the other tumour sites, such as breast, ovarian, renal cell and lung cancers have been mixed, but some benefit has been shown when compared to chemotherapy alone. ${ }^{18}$ The toxicity of treatment is important to consider and has been a subject of intense discussion between clinicians and drug regulatory bodies. The Food and Drug Administration (FDA) approved use of bevacizumab in GBM, colorectal, renal cell and metastatic HER2-negative breast cancer. However, despite accelerated approval for the latter, the overall benefits were subsequently deemed small in comparison to risks such as bleeding, venous thromboembolism and osteonecrosis of the jaw. As of November 2011, the FDA revoked it approval of bevacizumab in metastatic breast cancer, although it continues to be authorised in Europe. This emphasises the importance of carefully considering the balance between benefit and risk when developing novel targeted agents.

\section{VEGF and multikinase inhibitors}

Sunitinib and sorafenib are multitargeted receptor TKIs which affect the VEGF pathways and the tumour cell proliferation pathway of RAF/MEK/ERK (figure 2). By comparison with interferon- $\alpha$ in the treatment of metastatic renal cell carcinoma, sunitinib has demonstrated superiority in median PFS and in quality-of-life outcomes. ${ }^{22}$ Meanwhile, sorafenib has shown promise in those with advanced hepatocellular carcinoma by improving median survival and deterring radiological progression by approximately 3 months. ${ }^{23}$ The inhibition of multiple pathways may seem attractive, however, side effect profiles are usually more pronounced and need to be taken into consideration. In the case of sunitinib and sorafenib, for example, these include rash, hypertension, thyroid dysfunction and diarrhoea (table 2).

\section{TARGETING CHROMOSOMAL ABERRATIONS}

Perhaps the best example of purposeful and rational design of an anticancer drug based on tumour biology is imatinib in the treatment of chronic myeloid leukaemia (CML). CML is well known for the Philadelphia translocation, which leads to a fusion between Ableson tyrosine kinase (Abl) at chromosome 9 and break point cluster (Bcr) at chromosome 22. The resulting oncogenic fusion gene, Bcr-Abl, encodes a constitutively active kinase and the cancer cell develops a dependency to the resulting product which is now required to propagate its malignant phenotype, a phenomenon known as 'oncogene addiction'. Imatinib inhibits Ableson kinase, directly affecting the switch that propagates the chronic phase of CML. The use of imantinib has revolutionised the treatment of CML, resulting in high rates of remission and an almost doubling of 5 -years survival from $27.1 \%$ to $48.7 \%$ (post-imatinib). ${ }^{24}$ Patients started on imatinib have a low risk of progression to accelerated phase or blast crisis (81\% event-free survival at 8 years). ${ }^{25}$

Other oncogenic fusion genes have been discovered, including echinoderm microtubule-associated protein-like 4 (EML4) and anaplastic lymphoma kinase (ALK) in NSCLC. EML4-ALK is an aberrant fusion gene that propagates cell proliferation and occurs in a small proportion of patients with NSCLC who tend to be young, non-smokers, with adenocarcinoma histology. Crizotinib, an ALK TKI, has shown very impressive response 
rates and is now licensed for the treatment of relapsed, advanced-stage ALK-mutated NSCLC. ${ }^{26} 27$

Another recent addition to this list of treatments targeting specific tumour mutations is identification of the V600E mutation in the BRAF gene, which is found in $40-60 \%$ of patients with metastatic melanoma. The introduction of vemurafenib, a potent inhibitor of mutated BRAF, has brought about a stepchange change in the way the condition is managed. In the registration study, 6 months OS was $84 \%$ in the vemurafenib group compared to $64 \%$ in the control (dacarbazine chemotherapy) group. ${ }^{28}$ These results have led to the introduction of routine BRAF mutation testing in the management of metastatic melanoma.

\section{SYNTHETIC LETHALITY}

Synthetic lethality is the concept that in the relationship between two genes, loss of one gene function is not lethal to the cell due to reliance on a second gene product, however loss of function of both results in cell death. This allows targeting of cancer cells which already carry an inherent mutation in one gene as they can now be killed through therapeutic inhibition of the other. Normal cells, which carry both normal genes, are spared cell death.

The best examples of this approach are poly(ADP-ribose) polymerase 1 (PARP1) inhibitors in (breast cancer) BRCA-1 or BRCA-2 mutation ovarian and breast cancer. ${ }^{29}$ PARP is involved in repair of double-strand DNA breaks and, when inhibited, there is an over-reliance on the homologous recombination DNA repair pathway to maintain cellular integrity. BRCA mutation cancers are deficient in homologous recombination, and so, will be killed by PARP inhibition, whereas, normal cells should be unaffected. The PARP inhibitors iniparib and olaparib are undergoing clinical trials in BRCA-mutation cancers.

\section{IMMUNOTHERAPY AND CANCER VACCINES}

Although there have been innumerable attempts over the years to use the immune system in the treatment of cancer, results have largely been disappointing, with success limited to treatments such as intravesical Bacillus Calmette-Guerin (BCG) for localised bladder cancer. ${ }^{30}$ By contrast, new immunotherapeutic approaches have begun to yield much more impressive results. Targeting cytotoxic T-lymphocyte-associated antigen 4 (CTLA-4), a key molecule that induces anergy and immune tolerance in antigen-specific T cells, has been a significant development in the treatment of stage IV melanoma. ${ }^{31}$ Ipilimumab, an inhibitor of CTLA-4 signalling, improves median OS when combined with a peptide vaccine (glycoprotein 100) from 6.4 to 10.0 months, when compared to treatment with vaccine alone. ${ }^{32}$ Other T cell coinhibitory receptor targeting agents have been developed and have shown promising results. An early phase trial studying an anti-programmed death 1 (PD-1) monoclonal antibody in NSCLC has shown encouraging response rates and an acceptable side effect profile. ${ }^{33}$

Cervical cancer is intimately associated with infection by the human papillomavirus (HPV), particularly subtypes HPV-16 or HPV-18. Cervical carcinomas contain HPV DNA integrated into the host cell genome, and two viral oncogenes, E6 and E7, are implicated in $90 \%$ of cases. HPV E6 induces accelerated proteasomal degradation of p53, while E7 binds and degrades the $\mathrm{pRB}$ retinoblastoma tumour suppressor protein. ${ }^{34}$ This affects the tumour signalling and growth control of cells. Various strains of the virus have been linked to cancer, in particular cervical, anal and head and neck cancers. The FUTURE (Females United to Unilaterally Reduce Endo/Ectocervical
Disease) II trial randomised use of an HPV vaccine in 12167 women between the ages of 15 and 26 years. In those not previously infected with the HPV-16 or HPV-18, there was a lower incidence of high-grade cervical intraepithelial neoplasia (CIN) and a reported vaccine efficacy against high-grade CIN of $17 \%$. ${ }^{35}$ Since September 2008, there has been a national vaccination programme for girls aged 12-13 years. As cervical cancer is one of the leading causes of cancer-related death in developing countries, a worldwide vaccine programme would reduce cervical cancer risk on a global scale.

For patients with metastatic prostate cancer, there is an option to use immunotherapy which has recently been approved by the FDA. The sipuleucel-T is a vaccine that uses autologous peripheral-blood mononuclear cells and activated antigenpresenting cells to stimulate an antitumour response. The IMPACT (Immunotherapy for Prostate Adenocarcinoma Treatment) study demonstrated a survival benefit of 4.1 months in sipuleucel-T group (25.8 months) compared to placebo (21.7 months). ${ }^{36}$

\section{PROGRESS IN HORMONAL TREATMENT}

Androgens, oestrogens and progestins modulate the normal development of cells within the breast and prostate, while in the neoplastic cell these sex steroid hormones perpetuate growth. Although this does not correspond to a hallmark of cancer, hormones are required to perpetuate cancer cell growth, and the antihormonal agents were one of the first targeted agents in cancer drug development. These drugs spare the normal functions of the cell while depriving cancer cells of its important growth stimulus. Well known examples include oestrogen receptor modulators (eg, Tamoxifen) and aromatase inhibitors (eg, Letrozole), which have been beneficial in women with oestrogen receptor positive breast cancer. Hormonal therapy in breast cancer is relevant at all points in the treatment course, in the initial stages of management after surgery and in the metastatic setting.

Due to its dependence of prostate cancer on testosterone to drive cell growth, treatment has relied heavily on hormonal agents that cause chemical castration. Luteinizing hormone releasing hormone $(\mathrm{LHRH})$ analogues, such as goserelin, have been the mainstay of this for many years, however, it is common for resistance to emerge against. In such cases, termed castration-resistant prostate cancer, inhibition of a microsomal enzyme involved in androgen and oestrogen biosynthesis (Cytochrome P17) offers a new option for treatment. This inhibitor, Abiraterone, is well tolerated and has antitumour activity in combination with prednisolone in this population of heavily pretreated men. ${ }^{37}$ At 12.8 months follow-up, median OS was longer in the abiraterone-prednisone group than in the placebo-prednisone group (OS=14.8 vs 10.9 months). ${ }^{38}$

\section{BIOLOGICAL APPROACHES ON THE HORIZON Predicting resistance}

Knowledge of signalling pathways can clarify the way in which drug resistance develops. The resistance patterns and compensatory upregulation of neighbouring pathways found are new potential drug targets. For example, acquired resistance to erlotinib develops in many ways, including amplification of the tyrosine kinase receptor, mesenchymal epithelial transition (MET), and the development of secondary (T790M) mutations in the EGFR kinase domain. ${ }^{39}$ These discoveries have led to the development of T790M-targeted agents, as well as the combination use of erlotinib and MET inhibitors. ${ }^{40}$ 


\section{THE ERA OF PERSONALISED MEDICINE}

The development of novel technologies in parallel with advances in understanding of the molecular biology of cancer has empowered researcher and clinician to examine the whole genome, transciptosome, proteome and metabolome. These high-throughput tools allow a better understanding of the cancer cell and, thereby, identify biomarkers which can be applied to new and existing drug targets. ${ }^{41}{ }^{42}$ Technological advances in obtaining and processing tumour samples will be crucial in the development of personalised cancer treatment. The BATTLE (Biomarker-integrated Approaches of Targeted Therapy for Lung Cancer Elimination) trial demonstrated the feasibility of individualised lung cancer treatment through the use of biomarkers and tumour profiling to ensure appropriate molecular targets are correctly treated. ${ }^{43}$ On this basis, the future of oncology does not lie in applying a generic drug to every patient, but instead identifying the specific tumour biology within an individual to achieve the best possible treatment.

\section{THE OTHER HALLMARKS AND DRUG DEVELOPMENT}

Knowledge about the phenotypic characteristics of cancer has enabled us to design drugs against these specific features. Despite these advances, there are certain hallmarks of cancer that are elusive targets or have yet to yield an effective treatment. For example pro-apoptotic mimetics have been developed in an attempt to overcome the cancer cell's resistance to programmed cell death, and although there are promising in vitro results, human studies demonstrating benefit are lacking. ${ }^{44}$

Anti-inflammatory drugs, such as the cyclo-oxygenase-2 (COX-2) inhibitor celecoxib have shown a small but significant benefit in a variety of tumours, such as lung, breast and colorectal cancer. ${ }^{45}$ Whether this result is wholly due to antiinflammatory effects is not clear, however, as these agents also affect pathways responsible for angiogenesis and apoptosis.

\section{THE CHALLENGES OF DRUG DEVELOPMENT IN CANCER}

Although chemotherapy is still standard-of-care in the treatment of most cancers, biological targeted agents are increasingly commonly used in the clinical setting. However, for every biological agent that gets a license, there are many more that fail after initial trials. The costs and risks of taking a drug from the laboratory bench to the patient's bedside are enormous. The advent of personalised medicine means that the patient population that is actually suitable for each drug will probably continue to get smaller all the time. This raises difficult but important questions about how drugs are developed, tested and funded. Although the future of cancer treatment will rely on an integrated approach between scientists and clinicians using cutting edge technology to identify novel targets and design the relevant drugs, the more prosaic issue of money will be equally important.

\section{Main messages}

- Understanding tumour biology and the hallmarks of cancer has led to development of new drugs in oncology.

- New drugs consist of immunomodulatory agents and drugs that target proliferation, angiogenesis and growth-signalling pathways.

- Targeted therapies can be used as single agents or in combination with chemotherapeutic agents and radiotherapy in some cases.

\section{Current research questions}

- Are overall survival and progression-free survival the best primary endpoints to use when targeted therapies are trialled?

- Will our better understanding of tumour immunology and use of novel immunomodulatory agents lead to the widespread introduction of immunotherapy for cancer?

- If chemotherapeutic agents are considered cytotoxic, whereas a large number of targeted agents are cytostatic, what is the best method of assessing tumour response?

\section{Key references}

- Hanahan D, Weinberg RA. Hallmarks of cancer: the next generation. Cell 2011;144:646-4.

- Slamon DJ, Leyland-Jones B, Shak S, et al. Use of chemotherapy plus a monoclonal antibody against HER2 for metastatic breast cancer that overepresses HER2. N Engl J Med 2001;344:783-92.

- Deininger M, O'Brien SG, Guilhot F, et al. International Randomized Study of Interferon vs STI571 (IRIS) 8-year follow up: sustained survival and low risk for progression or events in patients with newly diagnosed Chronic Myeloid Leukemia in Chronic Phase (CML-CP) treated with imatinib. ASH, 2009.

- Kobayashi S, Boggon TJ, Dayaram T, et al. EGFR mutation and resistance of non-small cell lung cancer to gefitinib. $N$ Engl J Med 2005;352:786-92.

- Wistuba II, Gelovani JG, Jacoby JJ, et al. Methodological and practical challenges for personalized cancer therapies. Nat Rev Clin Oncol 2011;8:135-41.

\section{Self assessment questions}

Answer true $(T)$ or false $(F)$ for the below:

1. PARP inhibitors are drugs that have been developed for use in breast and ovarian cancer as this is a target for patients that express the BRCA $1 / 2$ mutation.

2. Vemurafenib is an inhibitor of the BRAF V500E mutation, which is licensed for use in metastatic melanoma.

3. Cardiotoxicity is a side effect of Trastuzumab, therefore, echocardiograms are required every 3 months to monitor these effects.

4. Her3 is a homodimer, and therefore, has no ligand.

5. Erlotinib is licensed for first-line use in lung cancer, but only in patients with EGFR mutations.

Competing interests None.

Provenance and peer review Commissioned; externally peer reviewed.

\section{REFERENCES}

1 Hanahan D, Weinberg RA. Hallmarks of cancer: the next generation. Cell 2011;144:646-74. 
2 Van Cutsem E, Nowacki M, Lang I, et al. Randomized phase III study of irinotecan and 5-FU/FA with or without cetuximab in the first-line treatment of patients with metastatic colorectal cancer (mCRC): The CRYSTAL trial. J Clin Oncol (Meeting Abstracts) 2007;25:4000.

3 Van Cutsem E, Kohne C-L, Hitre E, et al. Cetuximab and chemotherapy as initial treatment for metastatic colorectal cancer. N Engl J Med 2009;360:1408-17.

4 Bonner JA, Harari PM, Girait J, et al. Radiotherapy plus cetuximab for squamous-cell carcinoma of the head and neck. N Engl J Med 2006;354:567-78.

5 D Roock W, DeVriendt V, Normanno N, et al. KRAS, BRAF, PIK3CA, and PTEN mutations: implications for targeted therapies in metastatic colorectal cancer. Lancet Oncol 2011;12:594-603.

6 Fukuoka M, Wu Y-L, Thongprasert S, et al. Biomarker analyses and final overall survival results from a phase III, randomised, open-label, first-line study of Gefitinib versus Carboplatin/Paclitaxel in clinically selscted patients with advanced non-small cell lung cancer in Asia (IPASS). J Clin Oncol 2011;29:2866-74.

7 Lynch TJ, Bell DW, Sordella R, et al. Activating mutations in the epidermal growth factor receptor underlying responsiveness of non-small cell lung cancer to gefitinib. N Engl J Med 2004;350:2129-39.

8 Maemondo M, Inoue A, Kobayashi K, et al. Gefitinib or chemotherapy for non-small cell lung cancer with mutated EGFR. N Engl J Med 2010;362:2380-8.

9 Rosell R, Carcereny E, Gervais R, et al. Erlotinib versus standard chemotherapy as first-line treatment for European patients with advanced EGFR mutation-positive non-small-cell lung cancer (EURTAC): a multicentre, open-label, randomised phase 3 trial. Lancet Oncol 2012;13:239-46.

10 Slamon DJ, Leyland-Jones B, Shak S, et al. Use of chemotherapy plus a monoclonal antibody against HER2 for metastatic breast cancer that overepresses HER2. N Engl J Med 2001;344:783-92.

11 Smith I, Procter M, Gelber RD, et al. 2 year follow-up of trastuzumab after adjucant chemotherapy in HER2-positive breast cancer: a randomised controlled trial. Lancet 2007;369:29-36.

12 Miller K, Wang M, Gralow J, et al. Paclitaxel plus Bevacizumab versus Paclitaxel Alone for Metastatic Breast Cancer. N Engl J Med 2007:357:2666-76.

13 Bang Y-J, Van Cutsem E, Feyereislova A, et al. Trastuzumab in combination with chemotherapy versus chemotherapy alone for treatment of HER2-positive advanced gastric or gastro-oesophageal junction cancer (ToGA): a phase 3, open-label, randomised controlled trial. Lancet 2010;376:687-97.

14 Blackwell KL, Burstein HJ, Storniolo AM, et al. Randomized study of Lapatinib alone or in combination with trastuzumab in women with ErbB2-positive, trastuzumab-refractory metastatic breast cancer. J Clin Oncol 2010;28:1124-30.

15 Hudes $G$, Carducci M, Tomczak $P$, et al. Temsirolimus, interferon alfa, or both for advanced renal cell carcinoma. N Engl J Med 2007;356:2271-81.

16 Motzer RJ, Escudier B, Oudard S, et al. Efficacy of everolimus in advanced renal cell carcinoma: a double-blind, randomised, placebo-controlled phase III trial. Lancet 2008;372:449-56.

17 Ferrara N, Hillan KJ, Gerber H-P, et al. Discovery and development of bevacizumab an anti-VEGF antibody for treating cancer. Nature Rev Drug Discov 2004;3:391-400.

18 Shih T, Lindley C. Bevacizumab: an angiogenesis inhibitor for the treatment of solid malignancies. Clinical Therapeutics 2006;28:1779-802.

19 Jain RK. Normalizing tumor vasculature with anti-angiogenic therapy: a new paradigm for combination therapy. Nat Med 2001;7:987-9.

20 Hurwitz H, Fehrenbacher L, Novotny $W$, et al. Bevacizumab plus irinotecan, fluorouracil, and leucovorin for metastatic colorectal cancer. $N$ Engl J Med 2004;350:2335-42

21 Vredenburgh JJ, Desjardins A, Herdon JE II, et al. Bevacizumab plus irinotecan in recurrent glioblastoma multiforme. J Clin Oncol, 2007;30:4722-9.

22 Motzer RJ, Hutson TE, Tomczak $P$, et al. Sunitinib versus interferon alfa in metastatic renal cell carcinoma. N Engl J Med 2007;356:115-24.

23 Llovet JM, Ricci S, Mazzaferro V, et al. Sorafenib in advanced hepatocellular carcinoma. N Engl J Med 2008;359:378-90.

24 Lahaye $T$, Riehm B, Berger $U$, et al. Response and resistance in 300 patients with $B C R-A B L$ positive leukaemia treated with imatinib in a single centre: a 4.5 year follow-up. Cancer 2005;103:1659-69.
25 Deininger M, O'Brien SG, Guilhot F, et al. International Randomized Study of Interferon vs STI571 (IRIS) 8-year follow up: sustained survival and low risk for progression or events in patients with newly diagnosed Chronic Myeloid Leukemia in Chronic Phase (CML-CP) treated with imatinib. ASH, 2009.

26 Kwak EL, Bang YJ, Camidge DR, et al. Anaplastic lymphoma kinase inhibition in non-small cell lung cancer. N Engl J Med 2010;363:1693-703.

27 Shaw AT, Kim DW, Nakagawa K et al. Crizotinib versus chemotherapy in advanced ALK-positive lung cancer. N Engl J Med 2013;368:2385-94.

28 Chapman PB, Hauschild A, Robert C, et al. Improved survival with Vemurafenib in Melanoma with BRAF V600E mutation. N Engl J Med 2011;364:2507-16.

29 Fong PC, Boss DS, Yap TA, et al. Inhibition of poly(ADP-ribose) polymerase in tumors from BRCA mutation carriers. N Engl J Med 2009;361:123-34.

30 Davis ID. An overview of cancer immunotherapy. Immunol Cell Biol 2000:78:179-95.

31 Hoos A, Ibrahim R, Korman A, et al. Development of ipilimumab: contribution to a new paradigm for cancer immunotherapy. Semin Oncol 2010;37:533-46.

32 Hodi FS, O'Day SJ, McDermott DF, et al. Improved survival with ipilimumab in patients with metastatic melanoma. N Engl J Med 2010;363:711-23.

33 Brahmer JR, Tykodi SS, Chow LQM, et al. Safety and activity of anti-PD-L1 antibody in patients with advanced cancer. N Engl J Med 2012;366:2455-65.

34 Duensing S, Munger K. The human papillomavirus type 16 E6 and E7 oncoproteins independently induce numerical and structural chromosome instability. Cancer Res 2002:62:7075.

35 The FUTURE II Study Group. Quadrivalent vaccine against human papillomavirus to prevent high-grade cervical lesions. N Engl J Med 2007:356:1915-27.

36 Kantoff PW, Higano CS, Shore ND, et al. IMPACT Study Investigators, Sipuleucel-T immunotherapy for castration-resistant prostate cancer. N Engl J Med 2010;363:411-22.

37 Attard G, Reid A, Yap TA, et al. Phase I Clinical Trial of a selective inhibitor of CYP17, Abiraterone Acetate, confirms that Castration-resistant prostate cancer commonly remains hormone driven. J Clin Oncol 2008:26:4563-71.

38 De Bono JS, Logothetis CJ, Molina A, et al. Abiraterone and increased survival in metastatic prostate cancer. N Engl J Med 2011:364:1995-2005.

39 Kobayashi S, Boggon TJ, Dayaram T, et al. EGFR mutation and resistance of non-small cell lung cancer to gefitinib. N Engl J Med 2005;352:786-92.

40 Eder JP, Vande Woude GF, Boerner SA, et al. Novel therapeutics inhibitors of the c-met signaling pathway in cancer. Clin Cancer Res 2009:15:2207-14.

41 Petak I, Schwab R, Orfi L, et al. Integrating molecular diagnostics into anticancer drug discovery. Nat Rev Drugs Discovery 2010;9:523-35.

42 Wistuba II, Gelovani JG, Jacoby JJ, et al. Methodological and practical challenges for personalized cancer therapies. Nat Rev Clin Oncol 2011;8:135-41.

43 Kim S, Herbst RS, Wistuba II, et al. The BATTLE Trial: personalizing therapy for lung cancer. Cancer Discovery 2011;1:OF43-51.

44 Cragg MS, Harris C, Strasser A, et al. Unleashing the power of inhibitors of oncogenic kinases through BH3 mimetics. Nat Rev Cancer 2009;9:321-6.

45 Gasparini G, Longo R, Morabito A. Inhibitors of cyclo-oxygenase 2: a new class of anticancer agents? Lancet Oncol 2003;4:605-15.

\section{Answers}

1. $\mathrm{T}$

2. $F$

3. $T$

4. $F$

5. $F$ 